\title{
Plant-soil biodiversity relationships and nutrient retention in agricultural riparian zones of the Sacramento Valley, California
}

\author{
Anna Young-Mathews • Steven W. Culman • \\ Sara Sánchez-Moreno • A. Toby O'Geen • \\ Howard Ferris • Allan D. Hollander • Louise E. Jackson
}

Received: 11 July 2009/Accepted: 23 June 2010/Published online: 15 July 2010

(C) The Author(s) 2010. This article is published with open access at Springerlink.com

\begin{abstract}
Forested riparian buffers in California historically supported high levels of biodiversity, but human activities have degraded these ecosystems over much of their former range. This study examined plant communities, belowground biodiversity and indicators of multiple ecosystem functions of riparian areas across an agricultural landscape in the Sacramento Valley of California, USA. Plant, nematode and soil microbial communities and soil physical and chemical properties were studied along $50-\mathrm{m}$ transects at 20 sites that represented the different land use, soil and vegetation types in the landscape. Riparian zones supported greater plant diversity and nearly twice as much total carbon (C) per hectare compared to adjacent
\end{abstract}

A. Young-Mathews $(\bowtie) \cdot$ S. W. Culman .

A. Toby O'Geen · L. E. Jackson

Department of Land, Air and Water Resources,

University of California, One Shields Avenue,

Davis, CA 95616, USA

e-mail: ayoungmathews@ucdavis.edu

A. D. Hollander

Information Center for the Environment, University

of California, Davis, CA 95616, USA

H. Ferris

Department of Nematology, University of California,

Davis, CA 95616, USA

S. Sánchez-Moreno

Unidad de Productos Fitosanitarios, Instituto Nacional de Investigación y Tecnología Agraria y Alimentaria,

Crta. Coruña km 7.5, Madrid 28040, Spain land managed for agricultural uses, but had generally lower soil microbial and nematode diversity and abundance. When woody plant communities were present in the riparian zone, plant diversity and species richness were higher, and soil nitrate and plant-available phosphorus levels were lower. Belowground diversity and community structure, however, appeared to depend more on plant productivity (as inferred by vegetation cover) than plant diversity or species richness. Greater plant species richness, nematode food web structure, total microbial biomass, woody $\mathrm{C}$ storage and lower soil nitrate and phosphorus loading were correlated with higher visual riparian health assessment scores, offering the possibility of managing these riparian habitats to provide multiple ecosystem functions.

Keywords Aboveground-belowground relationships - Carbon storage - Ecosystem function . Nematodes $\cdot$ PLFA

\section{Introduction}

Riparian corridors are well recognized as havens of biodiversity, but over $80 \%$ of the original riparian area has been lost from North America and Europe over the past 200 years (Naiman et al. 1993). Human activities, especially conversion of land to agricultural uses, have resulted in a loss of habitat and related biodiversity and ecosystem services (Balvanera et al. 2006; Millennium Ecosystem Assessment 2005). "Working landscapes" 
that include agriculture as well as riparian and other natural ecosystems may protect biodiversity and ecosystem functions while maintaining agricultural productivity (Jordan et al. 2007).

In a heterogeneous agricultural landscape, management of riparian buffer zones changes soil properties, plant and soil biodiversity, nutrient cycling, and erosion potential (Lovell and Sullivan 2006; Neher et al. 2005). Vegetated riparian buffers filter agricultural nutrients and pollutants, reduce erosion, improve water quality and provide reservoirs for biodiversity (Lovell and Sullivan 2006; Peterjohn and Correll 1984; Richardson et al. 2007). Multi-species riparian buffers that include herbaceous as well as woody species may result in higher total productivity, soil carbon (C) sequestration, and nitrogen $(\mathrm{N})$ immobilization than monoculture plantings (Hill 1996; Marquez et al. 1999; Rowe et al. 2005; Tufekcioglu et al. 1998).

Soil microbial and nematode communities are important for ecosystem functions such as nutrient cycling and the stabilization of soil $\mathrm{C}$ from plant and microbial residues (Anderson 2000; Six et al. 2006), and soil biodiversity is thought to be essential for the maintenance of sustainable agricultural systems (Brussaard et al. 2007). Plant diversity and soil ecology are linked; greater diversity of plant species is often associated with greater plant productivity and soil microbial activity in field studies (Liu et al. 2008; Wardle et al. 2006; Zak et al. 2003). However, such studies have often been conducted at the field plot scale (Bardgett 2005; Ferris and Matute 2003; Porazinska et al. 2003), and thus have yielded little information on how these ecological phenomena extrapolate to the larger landscape scale where the collective effects of management decisions become evident (Swift et al. 2004; Tscharntke et al. 2005).

This study examined the relationship between above- and belowground biodiversity and ecosystem function of riparian areas in a heterogeneous agricultural landscape with different land use and soil types, located in the Sacramento Valley of California, USA. Land use varies in the degree of agricultural intensification, from non-irrigated rangelands to intensive, irrigated croplands, and management of canal and stream edges is largely under the control of individual landowners. Restoration of farm edges and riparian zones with native perennial plants has been a priority of some local stakeholders (Brodt et al. 2009; Robins et al. 2001).
Species-rich riparian forests once covered several million hectares (ha) in California's Sacramento Valley before clearing and draining by European settlers (Barbour et al. 1993; Roberts et al. 1980). Such forests are now restricted to narrow bands, typically 2-15 m wide, along streams and rivers, or have been eliminated. The following hypotheses were developed to compare ecosystem services of riparian areas with associated uplands over a gradient of land use intensity and physiographic conditions: (i) riparian areas support greater levels of plant and soil biodiversity, greater $\mathrm{C}$ stock per unit area and lower soil nutrient pools than adjacent agricultural land (crop fields or grazed grasslands); (ii) land use type affects these differences in biodiversity and nutrient pools; (iii) the presence of woody vegetation in the riparian zone increases the diversity and structure of above- and belowground communities and soil properties; and (iv) riparian zone health rating serves as an indicator of above- and belowground diversity and ecosystem functions.

\section{Materials and methods}

\section{Site description}

The study area is a $150-\mathrm{km}^{2}$ region of western Yolo County in the Sacramento Valley (northern Central Valley) of California, USA $\left(38^{\circ} \mathrm{N}, 122^{\circ} \mathrm{W}\right)$ that ranges from 27 to $105 \mathrm{~m}$ in elevation. The area consists of upland annual grasslands and oak savanna in the Coast Ranges to the west (used for cattle grazing and dry farm grain rotations) and flat, lowland alluvial fans and plains to the east (used for intensive irrigated cropland, including walnut orchards and rotations of both conventional and organic corn, processing tomatoes, wheat, oats and barley). Average monthly temperatures range from about $6-29^{\circ} \mathrm{C}$, and annual precipitation is $47 \mathrm{~cm}$ for this dry, Mediterranean climate, with rainfall mostly between November and April (WRCC 2009). Soils include the following great groups: Haploxeralfs, Haploxererts, Palexeralfs, Haploxerepts, and Xerorthents (Soil Survey Staff 2009). There are $212.9 \mathrm{~km}$ of waterways in the study area, which include both natural streams and constructed irrigation canals.

Twenty sites were sampled across the landscape, and were chosen to represent the range of soil and vegetation types found in the study area (see Culman et al. in press, Landscape Ecol, for details on site selection). Briefly, 
2,049 points across the landscape were randomly selected within $50 \mathrm{~m}$ of a waterway. Then 14 spatial datasets on soil characteristics, land use, vegetation and topography were compiled in a Geographic Information System (GIS). Multivariate cluster analysis was used to classify the points into five clusters, from which 20 sites were chosen to represent the variation within each cluster, thus providing a systematic sampling regime for the entire landscape.

At each site, a 50-m transect was established perpendicular to the waterway, running from the channel edge into the adjacent field. Sampling plots were established at three positions along this transect at a distance of approximately $0.5,9$ and $50 \mathrm{~m}$ from the bankfull channel edge (Fig. 1). These positions are referred to as A (agricultural field, which is either cropland or grazed grassland), B (floodplain bench above the waterway), and $\mathrm{C}$ (channel edge). Position $\mathrm{B}$ was located on the edge of the floodplain bench, or in the case of irrigation canals, where permanent vegetation could potentially be established, and ranged from 4 to $24 \mathrm{~m}$ from the channel edge.

Characterization of vegetation communities, riparian health and woody carbon storage

Vegetation and riparian characterization were conducted at each site from May to June of 2007. For community-level vegetation assessment, the riparian greenline method was used on 40-m transects to classify communities into the appropriate vegetation series (Sawyer and Keeler-Wolf 1995; Winward 2000). At the species level, vegetation surveys used Braun-Blanquet style relevé plots of $15-100 \mathrm{~m}^{2}$ for each of the three positions at each site (CNPS Vegetation Committee 2000); plants were identified according to Hickman (1993). Plants were classified into five main functional groups: (i) woody perennials, (ii) herbaceous natives, (iii) legumes, (iv) invasive/noxious weeds (USDA-NRCS 2009), and (v) other non-natives (excluding invasive/noxious weeds and legumes, but including crop species).

A quantitative visual assessment of riparian health was conducted along a 40-m reach at each site with a modification of the method for low gradient rangeland streams (Ward et al. 2003). Channel condition, access to the floodplain, bank stability, extent of natural riparian zone vegetation, macroinvertebrate habitat, pool variability and pool substrate were scored on a scale from 1 to 12 . The riparian health score was calculated as a percentage for each of the 20 sites.

To estimate woody $\mathrm{C}$ sequestration, the height, canopy dimensions and diameter at breast height (DBH) of all woody species $1.5 \mathrm{~m}$ or taller were recorded within the 40-m reach of the riparian zone (this zone varied in width from 14 to $40 \mathrm{~m}$, depending on surrounding land use and topography) following the Forest Project Protocol (California Climate Action Registry 2007). Aboveground wood biomass of each tree species was calculated using allometric equations based on DBH (Jenkins et al. 2003). Belowground tree biomass at each site was estimated using an allometric equation based on the calculated aboveground biomass density (Cairns et al. 1997). Shrub above- and belowground biomass were calculated based on equations from Smukler et al. (provisionally accepted, Agric Ecosyst Env), which related the ellipsoid volume of each shrub canopy to biomass. Total woody biomass per ha was calculated as the sum of above- and belowground tree and shrub biomass divided by the area surveyed. Total woody $\mathrm{C}$ storage $\left(\mathrm{Mg} \mathrm{ha}^{-1}\right)$ was calculated assuming a 50\% $\mathrm{C}$ content for all species (California Climate Action Registry 2007).
Fig. 1 Sampling positions relative to the waterway for the two land use types within the study area in the Sacramento Valley, California (not drawn to scale)

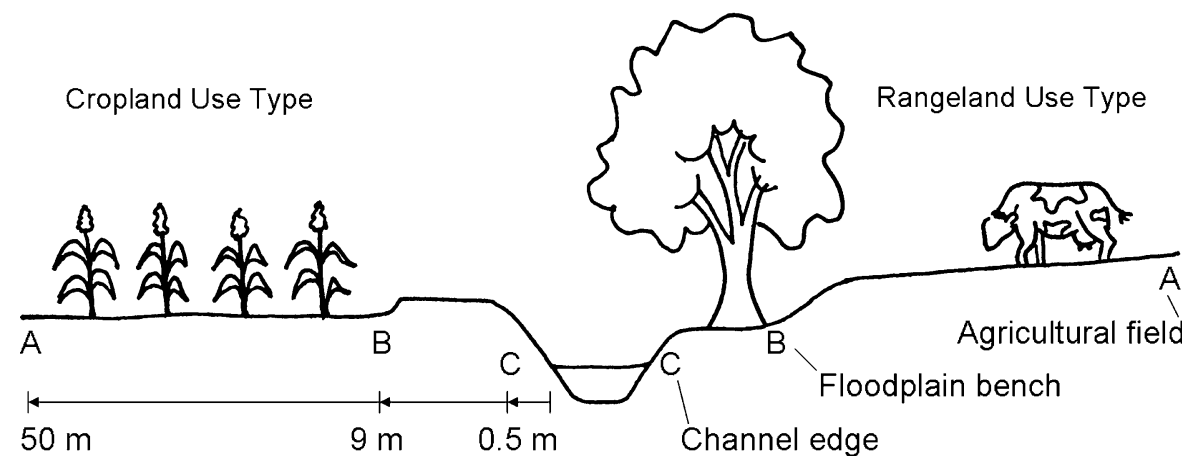


Soil sampling and profile descriptions

Soil profile characterization and sampling took place from late March to mid-April of 2007, when soil moisture was most similar across the landscape, and when soil temperatures were warm enough to facilitate soil microbial and nematode activity. Soil profiles $(1 \mathrm{~m} \times 1 \mathrm{~m} \times$ $1 \mathrm{~m}$ ) were dug at positions $\mathrm{A}, \mathrm{B}$ and $\mathrm{C}$ at each site, but in three cases no soil pit could be dug at position $\mathrm{B}$ because the canal was incised within an agricultural field.

Profile descriptions were performed using standard soil survey techniques (Schoeneberger et al. 2002). Four semi-quantitative morphologic indicators of soil quality were measured: (1) A-horizon darkening (indicating the accumulation of soil organic matter (SOM)); (2) A-horizon thickness (indicating a lack of soil disturbance); (3) depth to redoximorphic features (indicating presence of water table during some portion of the year); and (4) depth to a potentially root-limiting horizon, defined by root-restrictive bulk density in any horizon (e.g., greater than $1.7 \mathrm{~g} \mathrm{~m}^{-3}$ for loams or greater than $1.5 \mathrm{~g} \mathrm{~m}^{-3}$ for silty clay loams; USDA 2001) and/or an extremely firm consistence or textural classes with greater than $60 \%$ coarse fragments ( $>2 \mathrm{~mm}$ in diam.). A-horizon darkening (in any A-, Ap-, AB- or BA-horizons) was considered significant when there was a decrease of at least one unit in the Munsell color value from the surface to the next underlying horizon.

Soil was sampled from each pit, and from two $7.5-\mathrm{cm}$ diameter soil cores taken $2 \mathrm{~m}$ from the pit on either side, which were analyzed separately and treated as replicates. Depths were 0-15, 15-45, 45-75, and 75-100 cm. Each soil sample was homogenized, bagged, transported on ice, and stored at $4{ }^{\circ} \mathrm{C}$ for less than 8 days before analysis for soil moisture, inorganic N, nematodes and PLFA (surface samples only), and air drying for other soil properties.

Characterization of soil biotic communities, physical properties and nutrients

Nematodes were extracted by a modified sieving and Baermann funnel method (Barker 1985; Ferris and Matute 2003). Nematodes were identified to genus or family level, assigned to trophic groups (Yeates et al. 1993) and functional guilds (Bongers and Bongers 1998), and used to calculate structure index (an indicator of soil food web length and connectance; Ferris et al. 2001).
For microbial community composition and biomass, phospholipid fatty acids (PLFA) were extracted and analyzed (Bossio and Scow 1998), and identified on a Hewlett Packard 6890 gas chromatograph (J\&W Scientific, Folsom, CA). PLFA biomarkers were grouped into bacterial (actinomycetes, $\mathrm{Gram}^{+}$and $\mathrm{Gram}^{-}$), fungal and unspecific origins following Potthoff et al. (2006).

Inorganic $\mathrm{N}$ was extracted with $2 \mathrm{M} \mathrm{KCl}$, and analyzed colorimetrically for ammonium $\left(\mathrm{NH}_{4}{ }^{+}\right)$and nitrate $\left(\mathrm{NO}_{3}{ }^{-}\right)$on a Genesys 10VIS spectrophotometer (Thermo Fisher Scientific, Waltham, MA; Forster 1995; Miranda et al. 2001). Air-dried samples were crushed and sieved through a $2 \mathrm{~mm}$ screen. Particle size analysis was performed on a Coulter LS-230 Particle Size Analyzer (Beckman Coulter Inc., Miami, FL; Eshel et al. 2004). The Agriculture and Natural Resources Analytical Laboratory at the University of California at Davis analyzed soil for boron (B), total $\mathrm{N}$ and $\mathrm{C}, \mathrm{pH}$, Olsen phosphorus $(\mathrm{P})$ and exchangeable cations as described at http://groups.ucanr.org/danranlab/Soil_Analysis_2/.

Two bulk density samples were collected from each soil pit at two depths (1-7 and 27-33 cm) using a brass ring $\left(345 \mathrm{~cm}^{3}\right)$ to remove intact soil cores (Blake and Hartge 1986). Bulk density values of the bottom two soil layers were approximated based on the SSURGO data for the mapped soil type (Soil Survey Staff 2009). These values were used to calculate total soil $\mathrm{C}$ for the full 1-m profile using the percent soil $\mathrm{C}$ from each of the four sampled depth intervals.

Statistical analyses

Effects of land use and position from the channel edge on soil properties and plant, nematode and microbial diversity, richness and functional group abundance were analyzed using a mixed model ANOVA (based on repeated measures) with land use type as the betweensubject factor (two levels: rangeland and cropland), and position from the channel edge as the within-subject factor (three levels: A, B and C). This and all other tests were considered significant at $P<0.05$. One-way ANOVAs examined the simple effects of position for each land use type when there was a significant interaction, as well as for sites where woody-dominated communities (defined as narrowleaf willow series, blue oak series, Fremont cottonwood series, and valley oak series) were either absent or present in the riparian area. Mixed model three-way ANOVAs were used to analyze soil properties by depth, position from waterway and 
land use type. Data were normalized using $\log (x+1)$ or square root transformations when necessary to meet ANOVA assumptions. All ANOVAs were performed in SAS v9.1 (SAS Institute, Cary, NC) using the Tukey HSD test to determine differences between least square means.

Pearson's product moment correlations between riparian health rating, diversity measures, soil properties and soil profile indicators were run in $\mathrm{R}$ 2.7.2 (R Development Core Team 2008). Shannon's diversity index $\left(\mathrm{H}^{\prime}\right)$ and species richness were calculated with the diversity function in the vegan package in R. Pairwise comparisons of each group of biota were performed with Mantel tests to test the null hypotheses that no relationship exists between the two datasets (Mantel 1967). The test was performed in $\mathrm{R}$ with the mantel function in the vegan package using Bray-Curtis distance measures.

An indicator species analysis identified plant species that were indicators of good versus poor riparian health, based on species abundance (cover) and frequency (Dufrêne and Legendre 1997). A perfect score (1.0) indicates a species is both faithful (always present) and exclusive to a given category (McCune and Grace 2002). Indicator values were calculated using the duleg function in the labdsv package in $\mathrm{R}$, and significance was tested with 1,000 randomizations in a Monte Carlo test. For this purpose, the riparian health ratings were divided into four equally weighted health classes: poor (19.6-34.5\%), fair (34.6-49.4\%), moderate (49.5-64.3\%), and good (64.4-79.2\%).

\section{Results}

Diversity and structure of plant, nematode and microbial communities

A total of 114 plant species were identified (Appendix Table 6), and classified into five main functional groups: California state-listed invasive/noxious weeds (33 species), other herbaceous non-natives (excluding legumes and invasive/noxious weeds; 31 species), herbaceous natives ( 29 species), woody perennials (15 species), and non-native legumes (6 species). Of the total, 62 were annual species while 52 were perennials.

Plant diversity $\left(\mathrm{H}^{\prime}\right)$ was greater in the riparian positions, $\mathrm{B}$ and $\mathrm{C}$, than in the agricultural position, $\mathrm{A}$ (Table 1). Rangeland $H^{\prime}$ was greater than in the cropland land use type, and had an average of almost twice as many species. Positional differences were more pronounced in the rangeland than the cropland sites, with more species near the waterway in both cases.

Both woody perennial cover and native herbaceous species cover were greater in the riparian positions (B and C) than in position A in both land use types. Mean percent cover of total vegetation and legumes were both greater in rangeland than cropland. In the croplands, invasive/noxious weed cover was greater in riparian positions (B and $\mathrm{C}$ ) than position $\mathrm{A}$, while rangeland sites had greatest invasive/noxious weed cover at position B. The arable croplands had much greater cover of non-native species in the agricultural fields than in the riparian zone, but non-native species cover did not vary with position in the rangelands.

Nematode $\mathrm{H}^{\prime}$ and richness did not vary by position from the waterway or land use type (Table 1). There were 43 different nematode taxa (either genera or families), of which 14 were plant feeders or associates, 13 were bacterivores, six were fungivores, five were omnivores and four were predators. There were 10 common nematode taxa (found in over half of the samples), and 15 rare nematode taxa (found in less than $5 \%$ of the samples) (data not shown). Total nematode abundance and abundance of fungivores and plant feeders were greater at position A than at position $\mathrm{C}$ on the channel edge (Table 1). Both omnivores and predators were rare, but they were more abundant in agricultural fields and floodplain benches (positions A and $\mathrm{B}$ ), than at the waterway edge (position $\mathrm{C}$ ). Bacterivores were the only trophic group that varied between land use types, and were two times more abundant in cropland than rangeland sites.

Nematode structure index, a measure of soil food web length and connectance, ranged from 0 to 93.9 (on a scale of 0-100). In rangeland sites, it was greater in the field and riparian bench positions $(56.5 \pm 5.0$ and $48.4 \pm 3.6$ for positions $\mathrm{A}$ and $\mathrm{B}$, respectively) than at position $\mathrm{C}$ near the channel edge $(30.1 \pm 5.4, P<0.001)$. However, structure index did not differ by position in the cropland, and averaged $34.8 \pm 3.3$ for all sites.

Diversity of microbial PLFA biomarkers was greater in the agricultural position (A) than at position $\mathrm{C}$ at the edge of the channel (Table 1). Both the diversity and richness of the microbial biomarkers were greater for rangelands than croplands. There were 72 different PLFA biomarkers identified across the landscape: bacterial (18 biomarkers, composed of 
Table 1 Distribution of plant, nematode and microbial communities according to position from waterway $(\mathrm{A}=$ agricultural field, $\mathrm{B}=$ floodplain bench, $\mathrm{C}=$ channel edge) and two land use types in the Sacramento Valley, California

\begin{tabular}{|c|c|c|c|c|c|c|c|c|}
\hline & \multicolumn{4}{|c|}{ Position from waterway } & \multicolumn{3}{|c|}{ Land use type } & \multirow{2}{*}{$\begin{array}{l}\text { P*LU } \\
\text { Sig }\end{array}$} \\
\hline & A & B & $\mathrm{C}$ & Sig $^{\mathrm{a}}$ & Cropland & Rangeland & Sig & \\
\hline Plants & $(n=20)$ & $(n=20)$ & $(n=20)$ & & $(n=36)$ & $(n=24)$ & & \\
\hline Shannon's diversity index & $0.8 \pm 0.1 \mathrm{~b}$ & $1.5 \pm 0.1 \mathrm{a}$ & $1.5 \pm 0.1 \mathrm{a}$ & $* * *$ & $1.1 \pm 0.1$ & $1.5 \pm 0.1$ & $* *$ & NS \\
\hline Species richness & & & & & $7.5 \pm 0.8$ & $14.2 \pm 1.3$ & $* * *$ & $*$ \\
\hline Cropland & $4.5 \pm 0.9 \mathrm{~b}$ & $8.4 \pm 1.2 \mathrm{ab}$ & $9.6 \pm 1.4 \mathrm{a}$ & $* *$ & & & & \\
\hline Rangeland & $8.8 \pm 0.8 b$ & $13.8 \pm 1.0 \mathrm{~b}$ & $20.0 \pm 2.5 \mathrm{a}$ & $* * *$ & & & & \\
\hline Total cover $(\%)^{\mathrm{b}}$ & $46.5 \pm 7.5$ & $61.3 \pm 7.8$ & $62.2 \pm 6.9$ & NS & $45.9 \pm 5.8$ & $72.7 \pm 4.7$ & $*$ & NS \\
\hline Woody perennials & $1.9 \pm 1.9 \mathrm{~b}$ & $16.4 \pm 6.0 \mathrm{a}$ & $19.1 \pm 7.9 \mathrm{a}$ & $* *$ & $9.4 \pm 3.5$ & $17.0 \pm 6.8$ & NS & NS \\
\hline Herbaceous natives & $0.6 \pm 1.9 \mathrm{~b}$ & $2.1 \pm 0.6 \mathrm{a}$ & $5.1 \pm 1.5 \mathrm{a}$ & $* * *$ & $2.9 \pm 0.8$ & $2.0 \pm 0.7$ & NS & NS \\
\hline Legumes & $1.4 \pm 0.8$ & $2.9 \pm 0.9$ & $5.0 \pm 1.8$ & NS & $0.6 \pm 0.3$ & $6.9 \pm 1.5$ & $* * *$ & NS \\
\hline Invasive/noxious weeds & & & & & $23.2 \pm 4.5$ & $56.0 \pm 5.2$ & $* * *$ & $*$ \\
\hline Cropland & $5.8 \pm 3.8 \mathrm{~b}$ & $29.7 \pm 8.9 \mathrm{a}$ & $34.0 \pm 7.9 \mathrm{a}$ & $*$ & & & & \\
\hline Rangeland & $59.0 \pm 7.6 \mathrm{ab}$ & $69.2 \pm 9.0 \mathrm{a}$ & $39.8 \pm 8.2 \mathrm{~b}$ & $*$ & & & & \\
\hline Other non-natives ${ }^{\mathrm{c}}$ & & & & & $10.8 \pm 3.6$ & $3.3 \pm 1.7$ & NS & $* *$ \\
\hline Cropland & $26.8 \pm 9.0 \mathrm{a}$ & $3.8 \pm 1.9 \mathrm{~b}$ & $2.0 \pm 0.8 \mathrm{~b}$ & $* *$ & & & & \\
\hline Rangeland & $0.7 \pm 0.4$ & $2.0 \pm 1.2$ & $7.2 \pm 4.8$ & NS & & & & \\
\hline Nematodes & $(n=20)$ & $(n=18)$ & $(n=20)$ & & $(n=34)$ & $(n=24)$ & & \\
\hline Shannon's diversity index & $1.8 \pm 0.1$ & $1.9 \pm 0.1$ & $1.8 \pm 0.1$ & NS & $1.8 \pm 0.1$ & $1.9 \pm 0.1$ & NS & NS \\
\hline Taxa richness & $16.0 \pm 0.7$ & $16.0 \pm 0.8$ & $15.4 \pm 1.3$ & NS & $15.3 \pm 0.7$ & $16.5 \pm 0.9$ & NS & NS \\
\hline Total abundance $\left(100 \mathrm{~g}^{-1}\right.$ soil $)$ & $592 \pm 59 \mathrm{a}$ & $431 \pm 68 \mathrm{ab}$ & $309 \pm 58 \mathrm{~b}$ & $* *$ & $478 \pm 58$ & $397 \pm 42$ & NS & NS \\
\hline Bacterivores & $143 \pm 24$ & $125 \pm 30$ & $80 \pm 12$ & NS & $144 \pm 20$ & $75 \pm 11$ & $*$ & NS \\
\hline Fungivores & $272 \pm 35 \mathrm{a}$ & $158 \pm 25 b$ & $110 \pm 22 b$ & $* * *$ & $195 \pm 28$ & $161 \pm 19$ & NS & NS \\
\hline Plant feeders & $142 \pm 19 \mathrm{a}$ & $120 \pm 23 a b$ & $101 \pm 30 \mathrm{~b}$ & $*$ & $106 \pm 20$ & $142 \pm 18$ & NS & NS \\
\hline Omnivores + predators & $34.7 \pm 7.1 \mathrm{a}$ & $28.9 \pm 5.2 \mathrm{a}$ & $17.4 \pm 4.8 \mathrm{~b}$ & $*$ & $32.6 \pm 5.2$ & $18.9 \pm 3.4$ & NS & NS \\
\hline PLFA biomarkers & $(n=19)$ & $(n=18)$ & $(n=17)$ & & $(n=33)$ & $(n=21)$ & & \\
\hline Shannon's diversity index & $3.1 \pm 0.0 \mathrm{a}$ & $3.1 \pm 0.0 \mathrm{ab}$ & $3.1 \pm 0.0 \mathrm{~b}$ & $* * *$ & $3.1 \pm 0.0$ & $3.1 \pm 0.0$ & $*$ & NS \\
\hline PLFA richness & $39.9 \pm 1.2$ & $39.6 \pm 1.2$ & $36.0 \pm 1.3$ & NS & $36.5 \pm 0.9$ & $42.0 \pm 1.1$ & $* *$ & NS \\
\hline Total abundance $\left(\mathrm{nmol} \mathrm{g}^{-1}\right.$ soil) & $40.9 \pm 5.1$ & $41.8 \pm 5.1$ & $29.9 \pm 3.9$ & NS & $29.6 \pm 2.7$ & $50.5 \pm 4.7$ & $* * *$ & NS \\
\hline Actinomycetes & $2.4 \pm 0.3$ & $2.3 \pm 0.3$ & $1.8 \pm 0.2$ & NS & $1.8 \pm 0.1$ & $2.9 \pm 0.3$ & $* * *$ & NS \\
\hline $\mathrm{Gram}^{+}$bacteria & $8.7 \pm 1.0$ & $8.2 \pm 0.9$ & $6.1 \pm 0.8$ & NS & $6.3 \pm 0.5$ & $10.0 \pm 0.9$ & $* * *$ & NS \\
\hline Gram $^{-}$bacteria & $6.0 \pm 0.8$ & $6.2 \pm 0.8$ & $4.3 \pm 0.5$ & NS & $4.5 \pm 0.4$ & $7.2 \pm 0.7$ & $* *$ & NS \\
\hline Fungi & $5.4 \pm 0.8$ & $5.8 \pm 0.8$ & $4.1 \pm 0.6$ & NS & $3.8 \pm 0.4$ & $7.2 \pm 0.7$ & $* * *$ & NS \\
\hline
\end{tabular}

Mean \pm SE

a Significance for each main effect in the 2-way ANOVA, and the interaction of the two terms (position by land use type, P*LU): $P \leq 0.001=* * * ; \leq 0.01=* * ; \leq 0.05=*$. For significant interactions, simple effects are described instead of main effects for position. Means with the same lower-case letter within each row are not significantly different in Tukey comparisons at $\alpha=0.05$ level

b Cover does not necessarily total $100 \%$ as there may be canopy overlap or bare ground

c Non-native, herbaceous species excluding legumes and invasive/noxious weeds

seven $\mathrm{Gram}^{+}$bacteria, five $\mathrm{Gram}^{-}$bacteria, three actinomycetes, and three unspecific bacterial biomarkers), fungal (three biomarkers), and 51 unspecific biomarkers. Mean bacterial PLFA abundance was about three times higher than fungal PLFA abundance at each position from the waterway.

When group abundances were adjusted for total PLFA abundance, the relative abundance of fungi was 
still greater in rangelands than croplands $(14.0 \pm 0.2$ vs. $12.5 \pm 0.3 \%$, respectively; $P<0.01)$. The response for $\mathrm{Gram}^{+}$and $\mathrm{Gram}^{-}$bacteria was opposite, with relative abundance less in rangelands than croplands (19.9 \pm 0.4 vs. $21.6 \pm 0.3 \%$, respectively, $P=0.01$ for $\mathrm{Gram}^{+} ; 14.1 \pm 0.3$ vs. $15.2 \pm 0.2 \%$, respectively, $P<0.01$ for $\mathrm{Gram}^{-}$). Actinomycetes had an average relative abundance of $6.1 \pm 0.2 \%$ and did not vary with land use type or position.

\section{Soil properties}

Soil surface samples (0-15 cm depth) were on average $34 \%$ lower in total soil $\mathrm{C}$ at position $\mathrm{C}$ near the channel edge than at position A (i.e., fields or grasslands managed for agricultural production) (Table 2). The percentage of fine particles (silt and clay) was lower at the channel edge than at position $\mathrm{A}$. Rangeland sites had larger pools of $\mathrm{NH}_{4}{ }^{+}-\mathrm{N}$, total soil $\mathrm{C}$ and exchangeable $\mathrm{Ca}$ in the surface layer, and smaller pools of $\mathrm{NO}_{3}{ }^{-} \mathrm{N}$ and Olsen-P than the cropland sites. Total $\mathrm{C}$ was almost $50 \%$ higher in rangelands than croplands, and rangelands had a higher soil $\mathrm{C}$ to $\mathrm{N}$ ratio. In general, stronger positional gradients occurred for soil properties in rangelands than croplands, e.g. total soil N. Rangeland sites had higher $\mathrm{pH}$ and greater $\mathrm{B}$ concentration near the edge of the channel than in grazed fields. Weighted averages of soil nutrients for the four sampling depths from 0 to $100 \mathrm{~cm}$ showed similar trends for position and land use as for the $0-15 \mathrm{~cm}$ surface layer (Appendix Table 7). However, differences in weighted average values tended to be smaller.

Depth explained from $4 \%\left(\mathrm{NO}_{3}{ }^{-}-\mathrm{N}\right)$ to $42 \%$ (total C) of the variance in the three-way ANOVA model (data not shown). Total $\mathrm{C}$ and $\mathrm{N}, \mathrm{NH}_{4}{ }^{+}-\mathrm{N}, \mathrm{NO}_{3}{ }^{-}-\mathrm{N}$, Olsen-P and exchangeable $\mathrm{K}$ decreased with depth, while $\mathrm{pH}$ and exchangeable $\mathrm{Na}, \mathrm{Ca}$ and $\mathrm{Mg}$ increased with depth (data not shown). Effects of depth on total C and $\mathrm{N}$ were especially pronounced, with differences of about $50 \%$ between surface $(0-15 \mathrm{~cm})$ and deepest (75-100 cm) samples (data not shown).

Linking aboveground and belowground biota and soil properties

Vegetation and nematodes shared the greatest correlative structure out of the three biological communities, with a standardized Mantel statistic ( $r$, analogous to a correlation coefficient) of $0.24(P<0.001)$. PLFA communities were only weakly related to nematodes $(r=0.11$, $P<0.01)$ and vegetation $(r=0.08, P<0.05)$ in Mantel tests. Using Pearson's correlation tests, total percent plant cover correlated positively with nematode diversity and richness, as well as PLFA biomarker richness and abundance (Table 3). Vegetation species richness was also positively correlated with total PLFA abundance, which can be used as a proxy for total microbial biomass. Diversity of PLFA biomarkers was positively correlated with nematode diversity $(r=0.29$, $P<0.05)$ and PLFA richness was positively correlated with nematode richness $(r=0.32, P<0.05)$.

The presence of woody-dominated plant communities in the riparian zone increased total plant species diversity and richness (Fig. 2a, b). Nematode diversity and richness showed no differences (Fig. 2c, d), while PLFA diversity decreased in the riparian zone regardless of the presence of woody communities (Fig. 2e, f). Soil concentrations of $\mathrm{NO}_{3}{ }^{-}-\mathrm{N}$ and Olsen-P in the riparian positions were lower in sites with woody communities $\left(1.7 \pm 0.7\right.$ vs. $7.4 \pm 2.0 \mu \mathrm{g} \mathrm{NO}{ }_{3}^{-}$ $\mathrm{N} \mathrm{g}^{-1}, P=0.01$, and $14.1 \pm 1.4$ vs. $20.8 \pm 2.2 \mu \mathrm{g}$ Olsen-P $\mathrm{g}^{-1}, P=0.01$, for presence versus absence of woody communities, respectively). Total soil $\mathrm{C}$, however, did not vary in the presence of woody communities at either position B or C (data not shown).

Riparian health and ecosystem functions

Riparian health scores for the 20 sites ranged from $19.6 \%$ to $79.2 \%$, with an average score of $41.3 \pm 4.2 \%$. At position $C$ near the channel edge, riparian health scores correlated positively with plant diversity and richness, and with soil $\mathrm{NH}_{4}{ }^{+}-\mathrm{N}$ and $\mathrm{C}$ concentrations for the surface $0-15 \mathrm{~cm}$ (Table 4). In contrast, the riparian health scores were negatively correlated with soil $\mathrm{NO}_{3}{ }^{-}-\mathrm{N}$ and Olsen-P at position C. Both PLFA and nematode richness were positively correlated with riparian health scores at position $\mathrm{B}$ on the floodplain bench. Riparian health rating also correlated positively with nematode structure index at position $\mathrm{B}$, but showed a trend in the opposite direction at the more disturbed position $\mathrm{C}$.

Total C storage per ha (sum of soil C to 1-m depth and woody $\mathrm{C}$ ), was greater in the riparian zones of the rangelands than croplands or agricultural fields used for crops or grazing (Fig. 3). This difference was largely due to greater wood $\mathrm{C}$, as total soil $\mathrm{C}$ storage for the full $1-\mathrm{m}$ profile did not vary between positions 
Table 2 Soil properties in top $15 \mathrm{~cm}$ layer according to three positions from waterway $(\mathrm{A}=$ agricultural field, $\mathrm{B}=$ floodplain bench, $\mathrm{C}=$ channel edge) and two land use types in the Sacramento Valley, California

\begin{tabular}{|c|c|c|c|c|c|c|c|c|}
\hline & \multicolumn{4}{|c|}{ Position from waterway } & \multicolumn{3}{|l|}{ Land use type } & \multirow{2}{*}{$\begin{array}{l}\text { P*LU } \\
\text { Sig }\end{array}$} \\
\hline & $\mathrm{A}(n=20)$ & $\mathrm{B}(n=20)$ & $\mathrm{C}(n=20)$ & $\operatorname{Sig}^{\mathrm{a}}$ & $\begin{array}{l}\text { Cropland } \\
(n=36)\end{array}$ & $\begin{array}{l}\text { Rangeland } \\
(n=24)\end{array}$ & Sig & \\
\hline $\mathrm{NO}_{3}{ }^{-}-\mathrm{N}\left(\mu \mathrm{g} \mathrm{g}^{-1}\right)$ & $5.7 \pm 1.5$ & $4.2 \pm 1.2$ & $4.2 \pm 1.8$ & NS & $7.6 \pm 1.2$ & $0.4 \pm 0.1$ & $* * *$ & NS \\
\hline $\mathrm{NH}_{4}{ }^{+}-\mathrm{N}\left(\mu \mathrm{g} \mathrm{g}^{-1}\right)$ & $1.6 \pm 0.2$ & $1.7 \pm 0.3$ & $1.2 \pm 0.2$ & NS & $1.1 \pm 0.2$ & $2.0 \pm 0.2$ & $* *$ & NS \\
\hline Total N (\%) & & & & & $0.09 \pm 0.00$ & $0.11 \pm 0.01$ & NS & $* *$ \\
\hline Cropland & $0.11 \pm 0.01 \mathrm{a}$ & $0.09 \pm 0.01 \mathrm{ab}$ & $0.08 \pm 0.01 \mathrm{~b}$ & $*$ & & & & \\
\hline Rangeland & $0.13 \pm 0.01 \mathrm{a}$ & $0.13 \pm 0.01 \mathrm{a}$ & $0.06 \pm 0.01 \mathrm{~b}$ & $* * *$ & & & & \\
\hline Total C (\%) & $1.1 \pm 0.1 \mathrm{a}$ & $1.1 \pm 0.1 \mathrm{a}$ & $0.8 \pm 0.1 \mathrm{~b}$ & $* *$ & $0.9 \pm 0.0$ & $1.2 \pm 0.1$ & $* * *$ & NS \\
\hline $\mathrm{C}: \mathrm{N}$ ratio & $9.4 \pm 0.3$ & $10.3 \pm 0.4$ & $11.9 \pm 0.9$ & NS & $9.7 \pm 0.4$ & $11.9 \pm 0.6$ & $* *$ & NS \\
\hline Olsen-P $\left(\mu \mathrm{g} \mathrm{g}^{-1}\right)$ & $22.3 \pm 3.4$ & $19.6 \pm 1.8$ & $14.6 \pm 1.8$ & NS & $21.8 \pm 1.5$ & $14.3 \pm 2.6$ & $* *$ & NS \\
\hline $\mathrm{B}\left(\mu \mathrm{g} \mathrm{g}^{-1}\right)$ & & & & & $0.5 \pm 0.1$ & $0.1 \pm 0.0$ & $* * *$ & $* * *$ \\
\hline Cropland & $0.7 \pm 0.1$ & $0.3 \pm 0.1$ & $0.4 \pm 0.1$ & NS & & & & \\
\hline Rangeland & $0.0 \pm 0.0 \mathrm{~b}$ & $0.0 \pm 0.0 \mathrm{ab}$ & $0.1 \pm 0.1 \mathrm{a}$ & $*$ & & & & \\
\hline Exchangeable $\mathrm{K}^{\mathrm{b}}$ & $0.7 \pm 0.1 \mathrm{ab}$ & $0.8 \pm 0.0 \mathrm{a}$ & $0.5 \pm 0.1 \mathrm{~b}$ & $*$ & $0.7 \pm 0.1$ & $0.7 \pm 0.1$ & NS & NS \\
\hline Exchangeable $\mathrm{Na}^{\mathrm{b}}$ & & & & & $0.2 \pm 0.0$ & $0.3 \pm 0.1$ & NS & $* * *$ \\
\hline Cropland & $0.2 \pm 0.0 \mathrm{a}$ & $0.1 \pm 0.0 \mathrm{~b}$ & $0.2 \pm 0.1 \mathrm{ab}$ & $*$ & & & & \\
\hline Rangeland & $0.1 \pm 0.0 \mathrm{~b}$ & $0.1 \pm 0.0 \mathrm{~b}$ & $0.6 \pm 0.2 \mathrm{a}$ & $* * *$ & & & & \\
\hline Exchangeable $\mathrm{Ca}^{\mathrm{b}}$ & $13.3 \pm 1.0 \mathrm{ab}$ & $13.3 \pm 0.8 \mathrm{~b}$ & $15.0 \pm 0.9 \mathrm{a}$ & $*$ & $12.6 \pm 0.4$ & $15.9 \pm 1.1$ & $*$ & NS \\
\hline Exchangeable $\mathrm{Mg}^{\mathrm{b}}$ & $6.6 \pm 0.6$ & $5.6 \pm 0.4$ & $6.6 \pm 0.4$ & NS & $6.3 \pm 0.3$ & $6.1 \pm 0.5$ & NS & NS \\
\hline $\mathrm{pH}$ & & & & & $7.1 \pm 0.1$ & $7.1 \pm 0.2$ & NS & $* *$ \\
\hline Cropland & $6.5 \pm 0.1$ & $7.0 \pm 0.2$ & $7.3 \pm 0.2$ & NS & & & & \\
\hline Rangeland & $6.5 \pm 0.2 \mathrm{~b}$ & $6.9 \pm 0.2 \mathrm{~b}$ & $7.8 \pm 0.1 \mathrm{a}$ & $* * *$ & & & & \\
\hline Clay (\%) & $17.9 \pm 0.9 \mathrm{a}$ & $14.9 \pm 1.0 \mathrm{~b}$ & $14.1 \pm 0.8 \mathrm{~b}$ & $* * *$ & $16.1 \pm 0.6$ & $14.9 \pm 1.0$ & NS & NS \\
\hline Silt (\%) & & & & & $54.4 \pm 1.1$ & $50.4 \pm 2.1$ & NS & $*$ \\
\hline Cropland & $57.3 \pm 1.6$ & $53.4 \pm 1.9$ & $52.5 \pm 2.0$ & NS & & & & \\
\hline Rangeland & $58.0 \pm 2.4 \mathrm{a}$ & $49.9 \pm 3.7 \mathrm{ab}$ & $43.5 \pm 3.4 \mathrm{~b}$ & $*$ & & & & \\
\hline Sand (\%) & $24.5 \pm 1.8 \mathrm{~b}$ & $33.1 \pm 2.7 \mathrm{a}$ & $37.0 \pm 2.6 \mathrm{a}$ & $* * *$ & $29.5 \pm 1.6$ & $34.7 \pm 3.0$ & NS & NS \\
\hline
\end{tabular}

Mean \pm SE

a Significance for each main effect in the 2-way ANOVA, and the interaction of the two terms (position by land use type, P*LU): $P \leq 0.001=* * * ; \leq 0.01=* * ; \leq 0.05=*$. For significant interactions, simple effects are described instead of main effects for position. Means with the same lower-case letter within each row are not significantly different in Tukey comparisons at $\alpha=0.05$ level

b Exchangeable cations are given in meq $100 \mathrm{~g}^{-1}$ soil

or land use types (data not shown). Woody C storage in the riparian zone was positively correlated with riparian health scores $(r=0.58, P<0.01)$.

Indicator species analysis for riparian health classes at position $\mathrm{C}$ at the channel edge revealed that Johnsongrass (Sorghum halepense, a perennial statelisted noxious weed) was an indicator of poor riparian health (Indicator Value (IV) $=0.63, P<0.05$ ), while dogstail grass (Cynosurus echinatus, an annual nonnative) and pale spikerush (Eleocharis macrostachya, a perennial native) were strong indicators of good riparian health (IV $=0.75, P<0.01$ for both). At position $\mathrm{B}$ on the floodplain bench, no plant species was an indicator of poor riparian health, but hairy vetch (Vicia villosa, a non-native legume) and Fremont cottonwood (Populus fremontii, a native tree) were both indicators of good riparian health $(\mathrm{IV}=0.56, P<0.05$ and $\mathrm{IV}=0.50, P<0.05$, respectively).

Of our four indicators of soil quality based on soil profile characteristics, only A-horizon darkening correlated with riparian health scores (Table 5). 
Table 3 Pearson's correlation coefficients between aboveground and belowground biotic diversity, richness and abundance at sites in the Sacramento Valley, California $(n=60)$

\begin{tabular}{lccc}
\hline & $\begin{array}{l}\text { Vegetation } \\
\text { Shannon's } \\
\text { diversity }\end{array}$ & $\begin{array}{l}\text { Vegetation } \\
\text { species } \\
\text { richness }\end{array}$ & $\begin{array}{l}\text { Vegetation } \\
\text { total \% cover }\end{array}$ \\
\hline Nematodes & & & \\
Shannon's diversity & 0.02 & 0.16 & $\mathbf{0 . 3 8}$ \\
Taxa richness & 0.06 & 0.08 & $\mathbf{0 . 3 4}$ \\
Total abundance & -0.04 & -0.23 & -0.08 \\
PLFA biomarkers & & & \\
Shannon's diversity & -0.20 & -0.08 & 0.03 \\
Biomarker richness & 0.17 & 0.22 & $\mathbf{0 . 2 9}$ \\
Total abundance & 0.25 & $\mathbf{0 . 2 8}$ & $\mathbf{0 . 3 1}$ \\
\hline
\end{tabular}

Bold values are statistically significant at $P \leq 0.05$

A-horizon darkening also correlated positively with plant species richness and nematode $\mathrm{H}^{\prime}$. Thus, a change in soil surface color was the most informative soil quality indicator of biodiversity and riparian health.

\section{Discussion}

Riparian gradient and land use types

Riparian zones are often reservoirs of native plant diversity (Richardson et al. 2007), and indeed riparian positions here were richer in plant diversity than adjacent fields managed for agricultural purposes. However, native plant diversity in the riparian positions in this landscape was lower than in historical or remnant stands elsewhere in the Central Valley (Roberts et al. 1980; Sawyer and Keeler-Wolf 1995). This lower native plant diversity could be the legacy of historic land use change, including drainage of wetlands, clearing of forests, and tillage and land
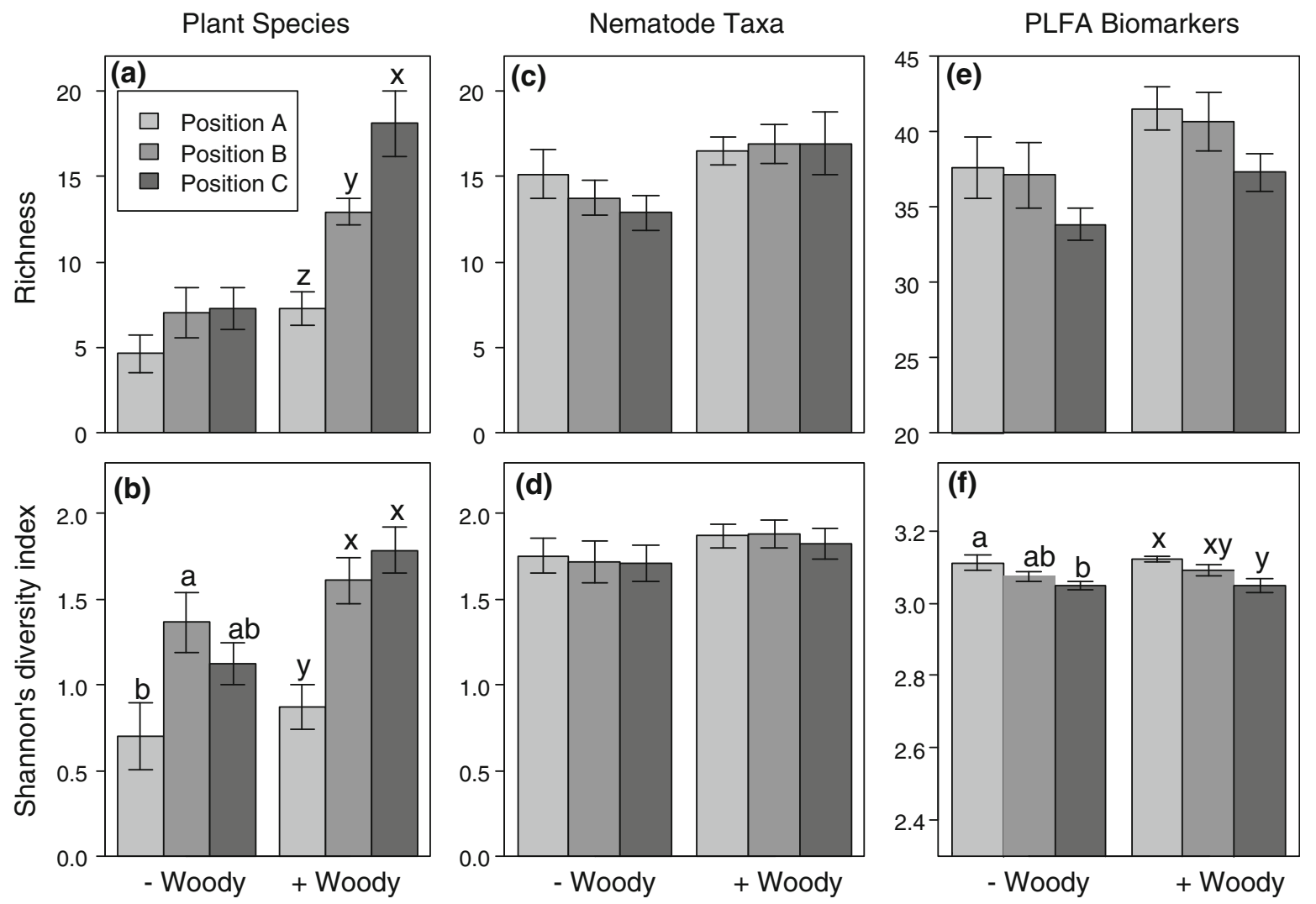

Fig. 2 Richness and diversity of plants (a, b), nematodes $(\mathbf{c}, \mathbf{d})$ and microbes (PLFA biomarkers) $(\mathbf{e}, \mathbf{f})$ in sites without ( - Woody, $n=8$ ) or with ( + Woody, $n=12$ ) woody riparian communities in the Sacramento Valley, California. Position
$\mathrm{A}=$ agricultural field, Position $\mathrm{B}=$ floodplain bench, Position $\mathrm{C}=$ channel edge. Means $\pm \mathrm{SE}$ with the same lower-case letter within each group of biota are not statistically different in Tukey means comparisons at $\alpha=0.05$ level 
Table 4 Pearson's correlation coefficients between riparian health scores and biotic and soil properties at two positions within the riparian zone ( $\mathrm{B}=$ floodplain bench, $\mathrm{C}=$ channel edge, $n=20$ for each) at sites in the Sacramento Valley, California

\begin{tabular}{|c|c|c|}
\hline & \multicolumn{2}{|c|}{ Riparian Health Scores } \\
\hline & Position B & Position $\mathrm{C}$ \\
\hline \multicolumn{3}{|l|}{ Plants } \\
\hline Shannon's diversity & 0.13 & $0.52 *$ \\
\hline Species richness & $0.58 * *$ & $0.70 * * *$ \\
\hline \multicolumn{3}{|l|}{ Nematodes } \\
\hline Shannon's diversity & 0.23 & 0.27 \\
\hline Taxa richness & $0.50 *$ & 0.09 \\
\hline Total abundance & -0.15 & 0.10 \\
\hline Structure index & $0.49 * * *$ & -0.29 \\
\hline \multicolumn{3}{|l|}{ PLFA biomarkers } \\
\hline Shannon's diversity & 0.30 & 0.01 \\
\hline Biomarker richness & $0.55^{*}$ & 0.45 \\
\hline Total abundance & $0.57 *$ & $0.54 *$ \\
\hline \multicolumn{3}{|l|}{ Soil $(0-15 \mathrm{~cm})$} \\
\hline $\mathrm{NO}_{3}{ }^{-}-\mathrm{N}\left(\mu \mathrm{g} \mathrm{g}^{-1}\right)$ & $-0.49 *$ & $-0.53 *$ \\
\hline $\mathrm{NH}_{4}^{+}-\mathrm{N}\left(\mu \mathrm{g} \mathrm{g}^{-1}\right)$ & $0.61 * *$ & $0.64 * *$ \\
\hline Total N (\%) & 0.36 & -0.35 \\
\hline Total C (\%) & $0.61 * *$ & $0.60 * *$ \\
\hline Olsen-P $\left(\mu \mathrm{g} \mathrm{g}^{-1}\right)$ & -0.43 & $-0.69 * * *$ \\
\hline
\end{tabular}

Significance levels: $P \leq 0.001=* * * ; \leq 0.01=* * ; \leq 0.05=*$

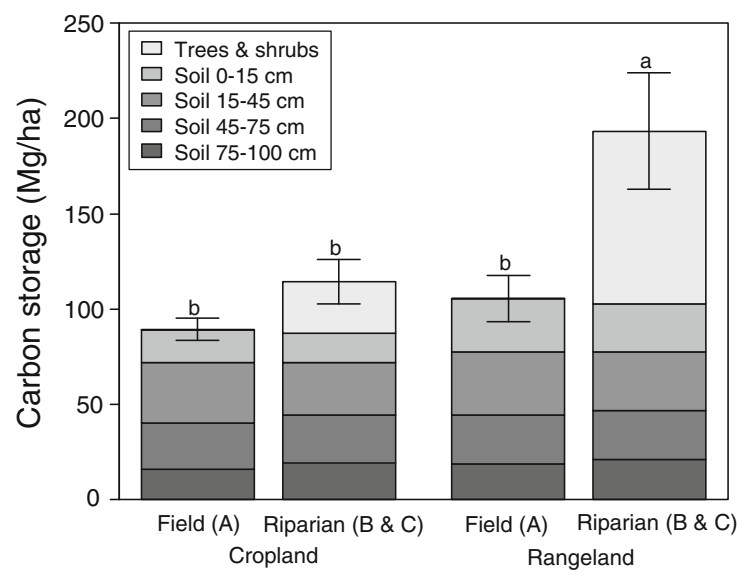

Fig. 3 Carbon storage in the top $1 \mathrm{~m}$ of soil and in woody biomass in the field (Position A) versus riparian zone (mean of Positions B and C) according to two land use types in the Sacramento Valley, California. Total mean C storage $\pm \mathrm{SE}$ denoted by the same lower-case letter is not statistically different in Tukey means comparisons at $\alpha=0.05$ level ( $n=12$ for cropland and $n=8$ for rangeland) planing for agriculture, dating back to the late $1800 \mathrm{~s}$ (Barbour et al. 1993).

Soil fungi and fungivorous nematodes often decrease with disturbance and/or wetter soils (Holland and Coleman 1987; Neher et al. 2005; Six et al. 2006). Thus, the greater abundance of fungivorous nematodes in position A may reflect drier and less disturbed soil conditions more conducive to fungal decomposition pathways further from the waterways. Most of the grazed rangelands were not tilled, and some of the irrigated cropland had not received spring tillage, whereas waterways had experienced substantial water and soil movement during the fall and winter rainy season. Surprisingly, abundance of PLFA fungal biomarkers did not vary according to position from the waterway, but the trend was toward fewer fungi near the channel edge.

Position $\mathrm{C}$ in the active stream channel was subject to frequent erosion, deposition, and submergence due to seasonal flooding and irrigation events. Low values of $\mathrm{C}$ and $\mathrm{N}$ at this landscape position are likely due to the dynamic nature of stream channel processes. In this setting, deposition and erosion can inhibit SOM accumulation (and associated $\mathrm{N}$ mineralization) either by deposition of parent material low in organic matter or by episodic stripping of carbon-rich floodplain soils during flood events. The high level of soil disturbance along the active stream channel may also explain the lower overall abundance of nematodes (Bouwman and Zwart 1994; Ferris et al. 2001; Lenz and Eisenbeis 2000).

Land use type was an important factor in explaining variance in plant and microbial diversity and functional group distribution, as well as many soil nutrients. For example, cropland sites had a higher relative abundance of $\mathrm{Gram}^{+}$and $\mathrm{Gram}^{-}$bacteria, and bacterivorous nematodes were also nearly twice as abundant in croplands as rangelands. These trends likely reflect the effects of tillage and agrochemical application on soil community diversity and function, as opportunistic bacteria and bacterivorous nematodes are known to increase with ecosystem disturbance (Ferris et al. 2001; Minoshima et al. 2007).

The relatively low invasive/noxious weed cover near rangeland waterways suggests interactions with native perennial woody and herbaceous species. Disturbance along the channel edge, and more intensive grazing pressure from cattle accessing water, may have contributed to the increased plant species richness of 
Table 5 Pearson's correlation coefficients ${ }^{a}$ between soil quality indicators and measures of biotic diversity and riparian health at sites in the Sacramento Valley, California

\begin{tabular}{|c|c|c|c|c|}
\hline Diversity measures & $\begin{array}{l}\text { Depth to potential } \\
\text { rooting barrier }\end{array}$ & $\begin{array}{l}\text { Depth to redoximorphic } \\
\text { features }\end{array}$ & $\begin{array}{l}\text { A-horizon } \\
\text { darkening }\end{array}$ & $\begin{array}{l}\text { A-horizon } \\
\text { thickness }\end{array}$ \\
\hline \multicolumn{5}{|l|}{ Plants } \\
\hline Shannon's diversity & 0.01 & -0.02 & 0.20 & -0.05 \\
\hline Species richness & -0.07 & -0.18 & 0.25 & -0.17 \\
\hline \multicolumn{5}{|l|}{ Nematodes } \\
\hline Shannon's diversity & 0.14 & -0.09 & 0.29 & 0.09 \\
\hline Taxa richness & 0.26 & 0.01 & 0.16 & 0.00 \\
\hline \multicolumn{5}{|l|}{ PLFA biomarkers } \\
\hline Shannon's diversity & -0.18 & -0.18 & 0.25 & 0.07 \\
\hline Biomarker richness & -0.17 & -0.09 & 0.16 & 0.07 \\
\hline Riparian health rating $^{\text {b }}$ & 0.07 & -0.17 & 0.33 & -0.23 \\
\hline
\end{tabular}

${ }^{a}$ Bold values are statistically significant at $P \leq 0.05$

b Riparian health correlations were run on data from positions B and C only $(n=40)$; all other correlations include data from all three positions from the waterway $(n=60)$

riparian positions by reducing the competitiveness of weedier species, as has been reported of frequent flooding and mowing in European floodplain rehabilitation projects (Gerard et al. 2008). The higher invasive/ noxious weed cover in cropland riparian zone positions than in the adjacent fields may be due to a lack of weed control measures in the riparian zone, whereas cultivation and herbicide applications are commonly practiced on the adjacent conventional crop fields planted with corn, tomatoes or grains (ARE-UC Davis 2008).

Plants, nematodes and soil microbes did not respond equally to differences in land use and the positional gradient from the waterway, reflecting different spatial and temporal scales of influence on these groups of organisms. While microbial communities in grasslands still show the effects of cultivation even 70 years after such practices have ceased (Steenwerth et al. 2003), plant communities can recover from such disturbance more quickly, especially when aided by active restoration (Giese et al. 2003; Richardson et al. 2007). Nematode communities, on the other hand, seemed to be most responsive to localized and seasonal resource availability and environmental conditions, instead of the larger landscape scale land use changes.

\section{Aboveground-belowground relationships}

Plant species richness and diversity increased where woody communities were present, possibly due to less disturbance by herbicide application, discing and scraping, mowing, grazing, burning and hand hoeing, all of which are riparian vegetation management practices commonly used in the region (Brodt et al. 2009). Nematode and PLFA diversity and richness were not affected by the presence of woody communities using ANOVA. However, another technique (data not shown), permutational multivariate analysis of variance (Anderson 2001), indicated that nematode communities appeared to be slightly responsive to woody plants, possibly due to changes in the quality and quantity of litter produced by different plant communities (Wardle et al. 2006). This statistical approach did not show any relationship between microbial community structure and the presence of woody communities, suggesting that land use and levels of disturbance may be more important than plant diversity (Drenovsky et al. 2009).

Woody plant communities also affected soil nutrient levels, as evident from lower concentrations of the readily available nutrients, $\mathrm{NO}_{3}{ }^{-}-\mathrm{N}$ and Olsen-P, in riparian positions containing woody communities. Where present, woody communities and their associated soil biota may have contributed to nutrient uptake and immobilization, as demonstrated for riparian forests in agricultural watersheds (Hill 1996; Lovell and Sullivan 2006; Peterjohn and Correll 1984). However, excess nutrients in riparian zones without trees may be an artifact of the scarcity of woody communities in croplands, where irrigated, fertilized fields may have been contributing these nutrients to the riparian zone via tailwater. 
Plant, nematode and microbial communities were positively but weakly correlated with each other in Mantel tests, indicating that the three community datasets were related, but that the majority of structure in these data was not accounted for. Trophic interactions would be expected to influence the structure of the microbial, nematode and vegetation communities (Waldrop et al. 2006; Zak et al. 2003). The stronger correlation between nematode and microbial diversity and richness was probably due to the link between microbial-feeding nematodes (the most abundant group in the nematode community) and their food source. Although no direct synchrony exists between nematode and bacterial growth (Papatheodorou et al. 2004), abundance of bacterial-feeding nematodes depends on bacterial biomass (Zelenev et al. 2004).

Net primary productivity may have been important in shaping nematode and microbial diversity and richness, based on their correlations with total plant cover. Positive correlations between above- and belowground diversity have been observed (De Deyn and Van der Putten 2005; Zak et al. 2003), but net primary productivity or specific plant traits appear to be stronger drivers of microbial and nematode diversity than plant diversity (Sánchez-Moreno et al. 2008; Viketoft et al. 2009; Waldrop et al. 2006).

Riparian health as an indicator of biodiversity and ecosystem function

Riparian zone health scores from visual assessments were highly correlated with many biodiversity and soil properties, e.g., total soil C, A-horizon darkening and nematode structure index. The mechanism by which healthier riparian zones increase SOM accumulation and soil food web structure is not clear, but disturbance is apparently a factor, since there were fewer correlations at the channel edge than on the floodplain bench.

Riparian health scores were negatively correlated with soil $\mathrm{NO}_{3}{ }^{-}-\mathrm{N}$ and Olsen-P, which may reflect the generally degraded state of the riparian zones in more intensive cropland sites where these nutrients were applied as fertilizers. Vegetation cover in these degraded riparian zones was mostly weedy, with Johnsongrass emerging as an indicator species. Greater riparian health scores, on the other hand, may indicate nutrient immobilization by more productive plant communities, where Fremont cottonwood and hairy vetch were found to be indicator species. The strong association between riparian health scores, soil quality, diversity measures and noxious weed distribution suggests that this simple visual scoring approach may prove useful for assessments by landowners and resource agencies. For example, local conservation and restoration programs led by non-governmental organizations (e.g., Audubon California) and governmental agencies (e.g., the Resource Conservation District and the USDA Natural Resources Conservation Service) are in need of inexpensive monitoring and evaluation tools.

\section{Conclusions}

In this complex agricultural landscape in a Mediterranean climate, riparian vegetation was a key element in management strategies to provide multiple ecosystem benefits. Healthier riparian zones, especially those with woody communities, provided more ecosystem functions, acting as $\mathrm{C}$ reservoirs, nutrient buffer strips to protect water quality, and habitat for above- and belowground biodiversity. The visual rating of riparian health, plant indicator species, and soil color differences were associated with indicators of biodiversity and ecosystem functions, and thus could serve as rapid assessment tools for land managers and restoration professionals. Maintaining or restoring native woody plant communities along these agricultural waterways appears to be a key element in improving the services they provide.

Acknowledgements We are very grateful to the farmers and ranchers in western Yolo County who allowed us access to their land, and to the staff of the Yolo County Resource Conservation District for helping to put us in touch with those growers. The Yolo Land and Cattle Co. was especially generous in field support. E. Dean of the UC Davis Herbarium kindly supplied plant identification services. We thank S. Sokolow, S. Smukler, F. Barrios-Masias, J. Seigies, M. Adams, B. Smith and R. Lee for field and laboratory assistance. This research was supported by the Kearney Foundation of Soil Science and the Orr Chair in Environmental Plant Science.

Open Access This article is distributed under the terms of the Creative Commons Attribution Noncommercial License which permits any noncommercial use, distribution, and reproduction in any medium, provided the original author(s) and source are credited.

\section{Appendix}




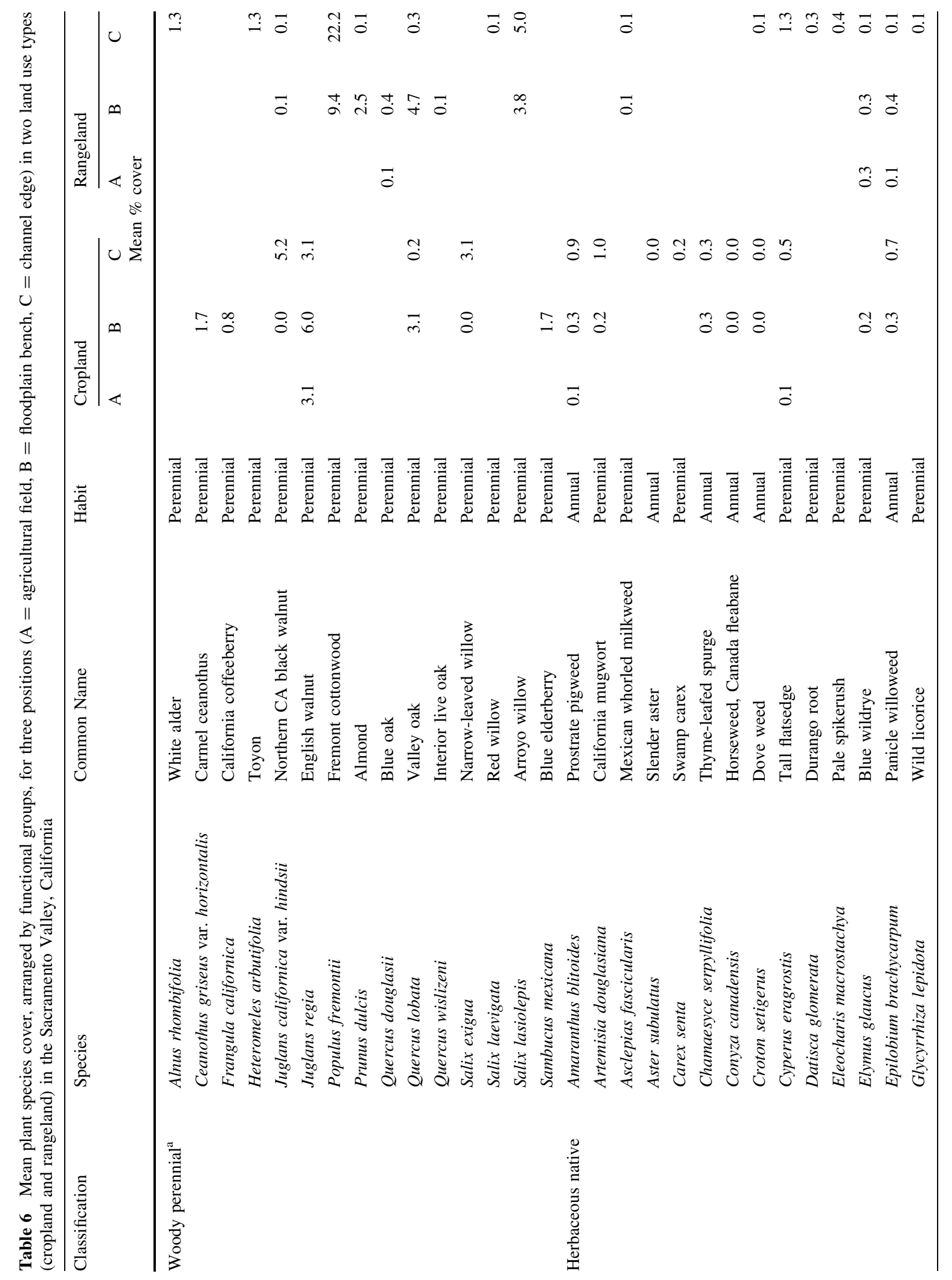




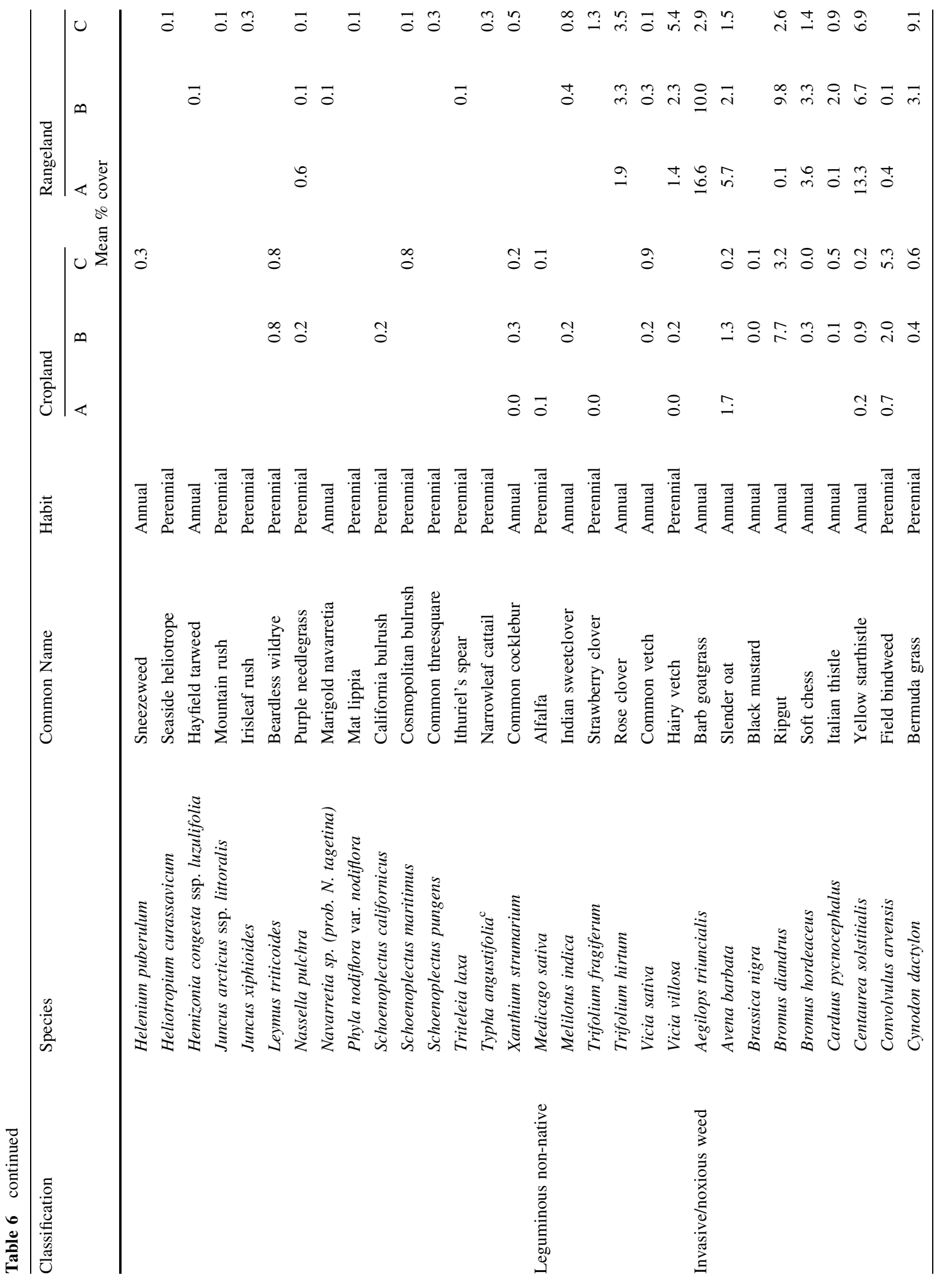




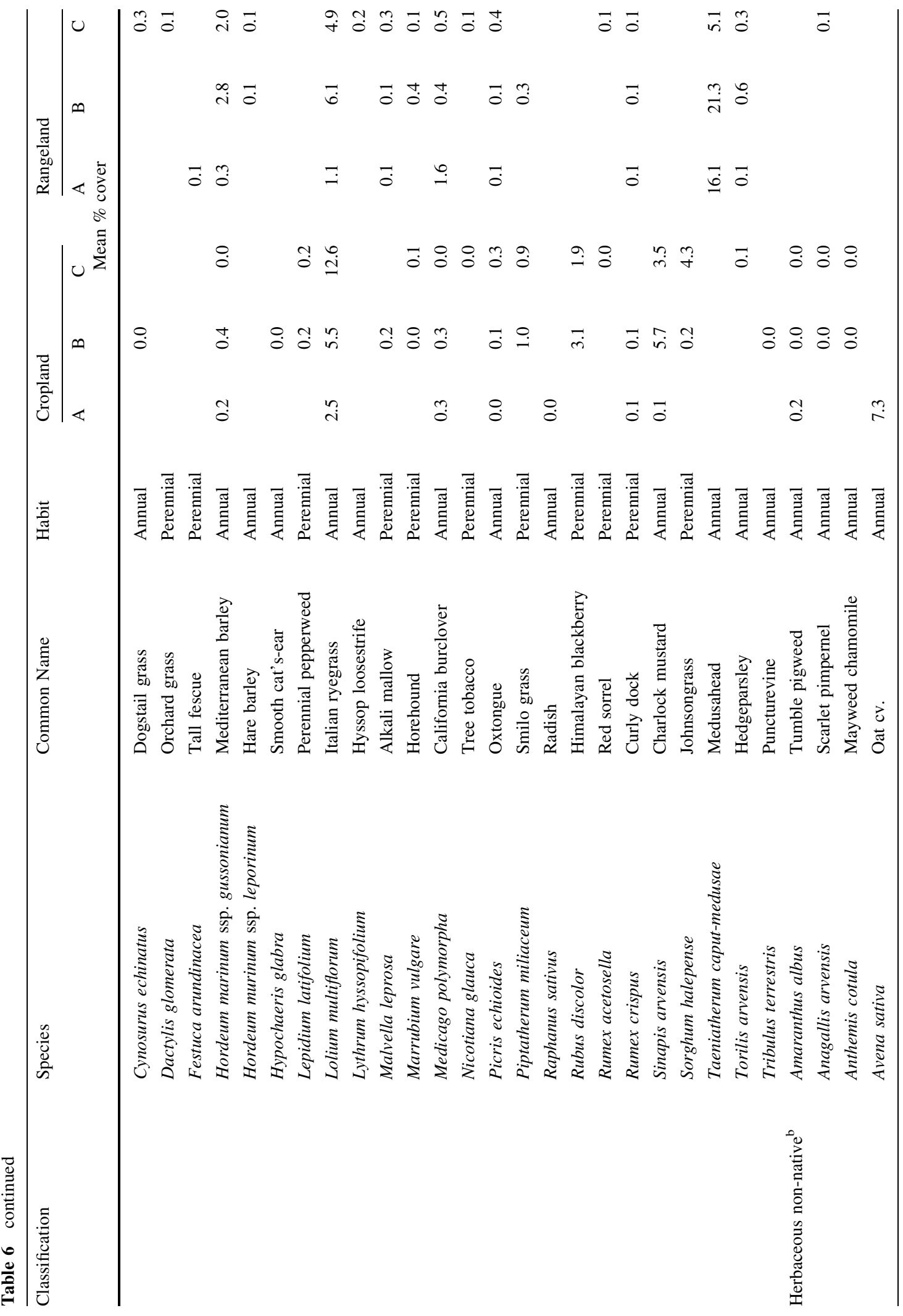




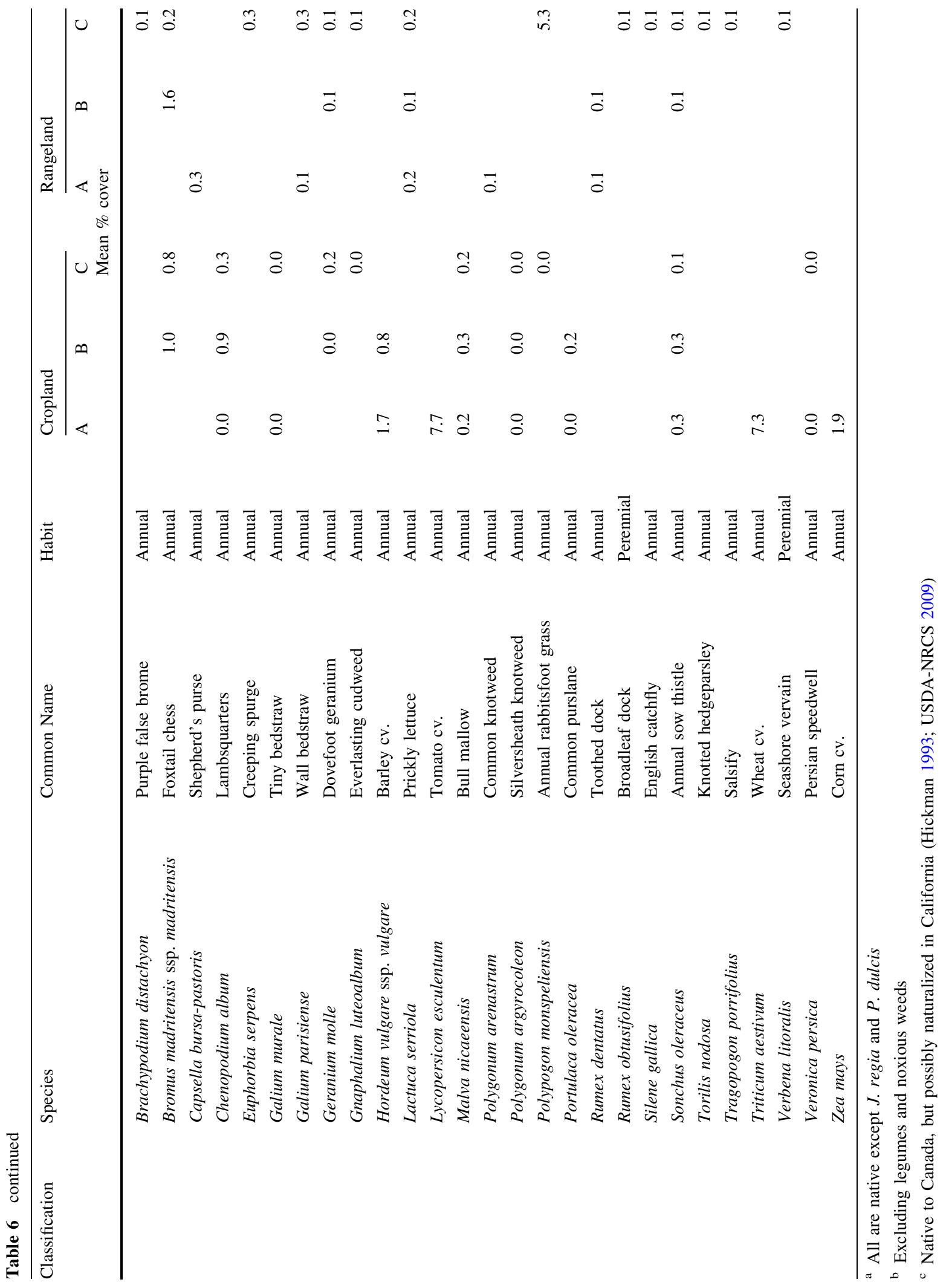




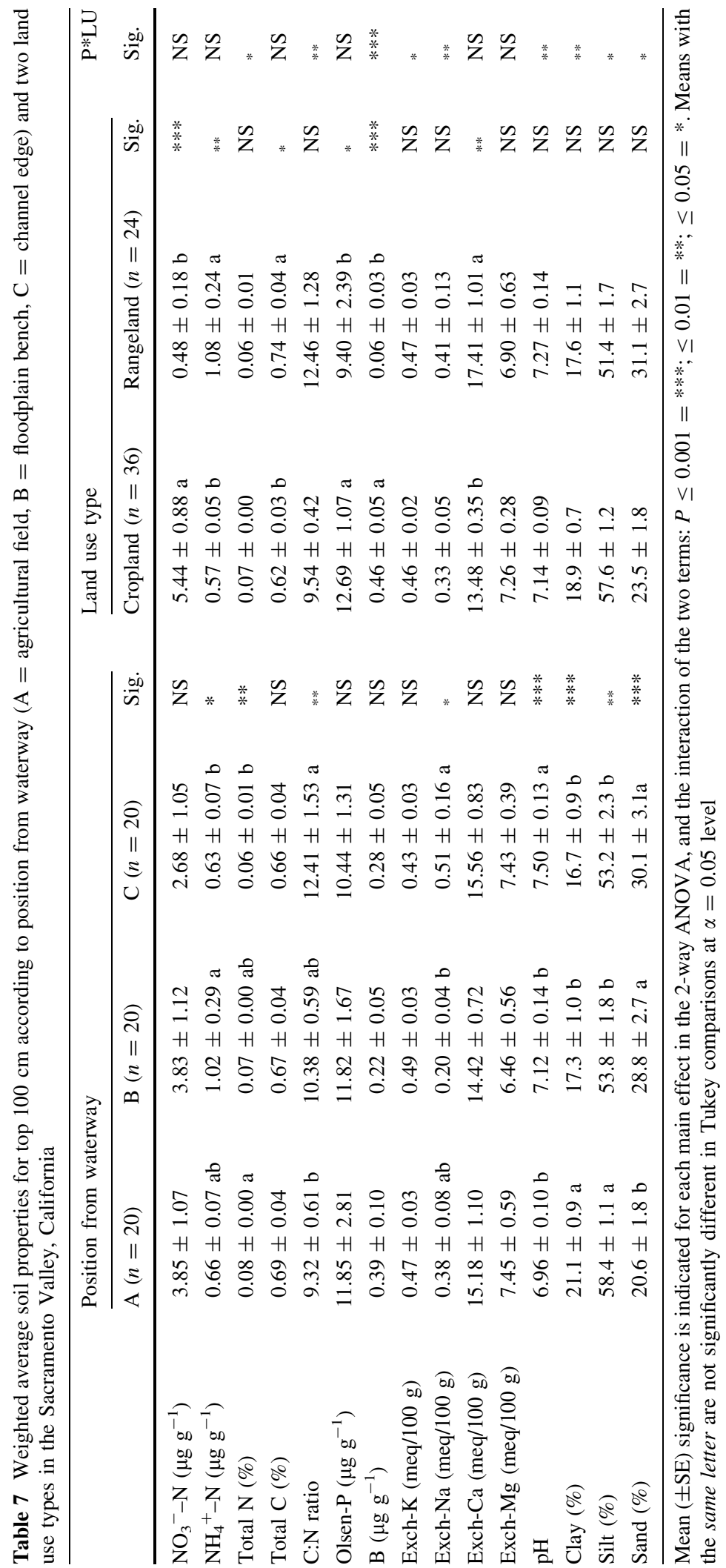




\section{References}

Anderson JM (2000) Food web functioning and ecosystem properties: problems and perception of scaling. In: Coleman DC, Hendrix PF (eds) Invertebrates as webmasters in ecosystems. CAB International, Wallingford, UK, pp 3-24

Anderson MJ (2001) A new method for non-parametric multivariate analysis of variance. Aust Ecol 26:32-46

ARE-UC Davis (2008) Current cost and return studies. Agricultural and resource economics. University of California, Davis. http://coststudies.ucdavis.edu/current.php. Accessed 17 Dec 2008

Balvanera P, Pfisterer AB, Buchmann N, He J-S, Nakashizuka T, Raffaelli D, Schmid B (2006) Quantifying the evidence for biodiversity effects on ecosystem functioning and services. Ecol Lett 9:1146-1156

Barbour M, Pavlik B, Drysdale F, Lindstron S (1993) California's changing landscapes: diversity and conservation of California vegetation. California Native Plant Society, Sacramento

Bardgett RD (2005) The biology of soil: a community and ecosystem approach. Oxford University Press, UK

Barker KR (1985) Nematode extraction and bioassays. In: Carter KR, Carter CC, Sasser JN (eds) An advanced treatise on Meloidogyne. North Carolina State University Graphics, Raleigh, pp 19-35

Blake GR, Hartge KH (1986) Bulk density. In: Klute A (ed) Methods of soil analysis: part 1 physical and mineralogical methods. ASA Monographs, Madison, WI, pp 364-367

Bongers T, Bongers M (1998) Functional diversity of nematodes. Appl Soil Ecol 10:239-251

Bossio DA, Scow KM (1998) Impacts of carbon and flooding on soil microbial communities: phospholipid fatty acid profiles and substrate utilization patterns. Microb Ecol 35:265-278

Bouwman LA, Zwart KB (1994) The ecology of bacterivorous protozoans and nematodes in arable soil. Agric Ecosyst Environ 51:145-160

Brodt S, Klonsky K, Jackson L, Brush SB, Smukler S (2009) Factors affecting adoption of hedgerows and other biodiversity-enhancing features on farms in California, USA. Agrofor Syst 76:195-206

Brussaard L, de Ruiter PC, Brown GG (2007) Soil biodiversity for agricultural sustainability. Agric Ecosyst Environ 121:233-244

Cairns MA, Brown S, Helmer EH, Baumgardner GA (1997) Root biomass allocation in the world's upland forests. Oecologia 111:1-11

California Climate Action Registry (2007) Forest project protocol version 2.1. http://www.climateregistry.org/resou rces/docs/protocols/industry/forest/forest_project_protocol_ version_2.1_sept2007.pdf. Accessed 15 Nov 2008

CNPS Vegetation Committee (2000) CNPS relevé protocol. California Native Plant Society, Sacramento

Culman SW, Young-Mathews A, Hollander AD, Ferris H, Sánchez-Moreno S, O'Geen AT, Jackson LE (in press) Biodiversity is associated with indicators of soil ecosystem functions over a landscape gradient of agricultural intensification. Landscape Ecol. doi:10.1007/s10980-0109511-0
De Deyn GB, Van der Putten WH (2005) Linking aboveground and belowground diversity. Trends Ecol Evol 20:625-633

Drenovsky RE, Steenwerth KL, Jackson LE, Scow KM (2009) Land use and climate factors structure regional patterns in soil microbial communities. Global Ecol Manag 19:27-39

Dufrêne M, Legendre P (1997) Species assemblages and indicator species: the need for a flexible asymmetrical approach. Ecol Monogr 67:345-366

Eshel G, Levy GJ, Mingelgrin U, Singer MJ (2004) Critical evaluation of the use of laser diffraction for particle-size distribution analysis. Soil Sci Soc Am J 68:736-743

Ferris H, Matute MM (2003) Structural and functional succession in the nematode fauna of a soil food web. Appl Soil Ecol 23:93-110

Ferris H, Bongers T, de Goede RGM (2001) A framework for soil food web diagnostics: extension of the nematode faunal analysis concept. Appl Soil Ecol 18:13-29

Forster JC (1995) Soil nitrogen. In: Alef K, Nannipieri P (eds) Methods in applied soil microbiology and biochemistry. Academic Press, San Diego, pp 79-87

Gerard M, El Kahloun M, Rymen J, Beauchard O, Meire P (2008) Importance of mowing and flood frequency in promoting species richness in restored floodplains. J Appl Ecol 45:1780-1789

Giese LAB, Aust WM, Kolka RK, Trettin CC (2003) Biomass and carbon pools of disturbed riparian forests. For Ecol Manag 180:493-508

Hickman JC (ed) (1993) The Jepson manual: higher plants of California. University of California Press, Berkeley

Hill AR (1996) Nitrate removal in stream riparian zones. J Environ Qual 25:743-755

Holland EA, Coleman DC (1987) Litter placement effects on microbial and organic matter dynamics in an agroecosystem. Ecology 68:425-433

Jenkins JC, Chojnacky DC, Heath LS, Birdsey RA (2003) National-scale biomass estimators for United States tree species. For Sci 49:12-35

Jordan N, Boody G, Broussard W, Glover JD, Keeney D, McCown BH, McIsaac G, Muller M, Murray H, Neal J, Pansing C, Turner RE, Warner K, Wyse D (2007) Environment - sustainable development of the agricultural bioeconomy. Science 316:1570-1571

Lenz R, Eisenbeis G (2000) Short-term effects of different tillage in a sustainable farming system on nematode community structure. Biol Fertl Soils 31:237-244

Liu ZF, Liu GH, Fu BJ, Zheng XX (2008) Relationship between plant species diversity and soil microbial functional diversity along a longitudinal gradient in temperate grasslands of Hulunbeir, Inner Mongolia, China. Ecol Res 23:511-518

Lovell ST, Sullivan WC (2006) Environmental benefits of conservation buffers in the United States: evidence, promise, and open questions. Agric Ecosyst Environ 112:249-260

Mantel N (1967) Detection of disease clustering and a generalized regression approach. Cancer Res 27:209-220

Marquez CO, Cambardella CA, Isenhart TM, Schultz RC (1999) Assessing soil quality in a riparian buffer by testing organic matter fractions in central Iowa, USA. Agrofor Syst 44:133-140 
McCune B, Grace JB (2002) Analysis of ecological communities. MjM Software Design, Gleneden Beach, OR

Millennium Ecosystem Assessment (2005) Ecosystems and human well-being: biodiversity synthesis. World Resources Institute, Washington DC

Minoshima H, Jackson LE, Cavagnaro TR, Sánchez-Moreno S, Ferris H, Temple SR, Mitchell JP (2007) Soil food webs and carbon dynamics in response to conservation tillage in legume rotations in California. Soil Sci Soc Am J 71:952-963

Miranda KM, Espey MG, Wink DA (2001) A rapid, simple spectrophotometric method for simultaneous detection of nitrate and nitrite. Nitric Oxide-Biol Chem 5:62-71

Naiman RJ, Decamps H, Pollock M (1993) The role of riparian corridors in maintaining regional biodiversity. Ecol Appl 3:209-212

Neher DA, Wu J, Barbercheck ME, Anas O (2005) Ecosystem type affects interpretation of soil nematode community measures. Appl Soil Ecol 30:47-64

Papatheodorou EM, Argyropoulou MD, Stamou GP (2004) The effects of large- and small-scale differences in soil temperature and moisture on bacterial functional diversity and the community of bacterivorous nematodes. Appl Soil Ecol 25:37-49

Peterjohn WT, Correll DL (1984) Nutrient dynamics in an agricultural watershed: observations on the role of a riparian forest. Ecology 65:1466-1475

Porazinska DL, Bardgett RD, Blaauw MB, Hunt HW, Parsons AN, Seastedt TR, Wall DH (2003) Relationships at the aboveground-belowground interface: plants, soil biota, and soil processes. Ecol Monogr 73:377-395

Potthoff M, Steenwerth KL, Jackson LE, Drenovsky RE, Scow KM, Joergensen RG (2006) Soil microbial community composition as affected by restoration practices in California grassland. Soil Biol Biochem 38:1851-1860

R Development Core Team (2008) R: a language and environment for statistical computing. R Foundation for Statistical Computing, Vienna, Austria

Richardson DM, Holmes PM, Esler KJ, Galatowitsch SM, Stromberg JC, Kirkman SP, Pysek P, Hobbs RJ (2007) Riparian vegetation: degradation, alien plant invasions, and restoration prospects. Divers Distrib 13:126-139

Roberts WG, Howe JG and Major J (1980) A survey of riparian forest flora and fauna in California. In: Sands A (ed) Riparian forests in California: their ecology and conservation. University of California, Davis, pp 3-20

Robins P, Holmes RB, Laddish K (2001) Bringing farm edges back to life. Yolo County Resource Conservation District, Woodland, CA

Rowe EC, Van Noordwijk M, Suprayogo D, Cadisch G (2005) Nitrogen use efficiency of monoculture and hedgerow intercropping in the humid tropics. Plant Soil 268:61-74

Sánchez-Moreno S, Smukler S, Ferris H, O'Geen AT, Jackson LE (2008) Nematode diversity, food web condition, and chemical and physical properties in different soil habitats of an organic farm. Biol Fertl Soils 44:727-744

Sawyer JO, Keeler-Wolf T (1995) Manual of California vegetation. California Native Plant Society, Sacramento

Schoeneberger PJ, Wysocki DA, Benham EC and Broderson WD (eds) (2002) Field book for describing and sampling soils, version 2.0. Natural Resources Conservation Service, USDA, National Soil Survey Center, Lincoln, NE

Six J, Frey SD, Thiet RK, Batten KM (2006) Bacterial and fungal contributions to carbon sequestration in agroecosystems. Soil Sci Soc Am J 70:555-569

Smukler SM, Jackson LE, Sánchez-Moreno S, Fonte SJ, Ferris H, Klonsky K, O'Geen AT, Scow KM, and Steenwerth KL (submitted) Biodiversity and multiple ecosystem functions in an organic farmscape. Agric Ecosyst Env

Soil Survey Staff (2009) National soil survey characterization data. USDA-NRCS, Soil Survey Laboratory, National Soil Survey Center, Lincoln, NE

Steenwerth KL, Jackson LE, Calderon FJ, Stromberg MR, Scow KM (2003) Soil community composition and land use history in cultivated and grassland ecosystems of coastal California. Soil Biol Biochem 35:487-500

Swift MJ, Izac AMN, van Noordwijk M (2004) Biodiversity and ecosystem services in agricultural landscapes: are we asking the right questions? Agric Ecosyst Environ 104: 113-134

Tscharntke T, Klein AM, Kruess A, Steffan-Dewenter I, Thies C (2005) Landscape perspectives on agricultural intensification and biodiversity - ecosystem service management. Ecol Lett 8:857-874

Tufekcioglu A, Raich JW, Isenhart TM, Schultz RC (1998) Fine root dynamics, coarse root biomass, root distribution, and soil respiration in a multispecies riparian buffer in Central Iowa, USA. Agrofor Syst 44:163-174

USDA (2001) Rangeland soil quality: compaction. USDA Natural Resources Conservation Service. http://www.nys envirothon.org/Soils_CD/sq_info/RSQIS4.pdf. Accessed 2 Feb 2009

USDA-NRCS (2009) California state-listed noxious weeds. In: The PLANTS database. National Plant Data Center, Baton Rouge, LA. http://plants.usda.gov. Accessed 7 Jun 2009

Viketoft M, Bengtsson J, Sohlenius B, Berg MP, Petchey O, Palmborg C, Huss-Danell K (2009) Long-term effects of plant diversity and composition on soil nematode communities in model grasslands. Ecology 90:90-99

Waldrop MP, Zak DR, Blackwood CB, Curtis CD, Tilman D (2006) Resource availability controls fungal diversity across a plant diversity gradient. Ecol Lett 9:1127-1135

Ward TA, Tate KW and Atwill ER (2003) Visual Assessment of Riparian Health. Rangeland monitoring series. UC ANR, Davis, CA

Wardle DA, Yeates GW, Barker GM, Bonner KI (2006) The influence of plant litter diversity on decomposer abundance and diversity. Soil Biol Biochem 38:1052-1062

Winward AH (2000) Monitoring the vegetation resources in riparian areas. U.S. Department of Agriculture, Forest Service, Rocky Mountain Research Station, Ogden, UT

WRCC (2009) Western Regional Climate Center. http://www. wrcc.dri.edu/cgi-bin/cliMAIN.pl?ca9781. Accessed 29 May 2009

Yeates GW, Bongers T, Degoede RGM, Freckman DW, Georgieva SS (1993) Feeding habits in soil nematode families and genera: an outline for soil ecologists. J Nematol 25:315-331

Zak DR, Holmes WE, White DC, Peacock AD, Tilman D (2003) Plant diversity, soil microbial communities, and 
ecosystem function: are there any links? Ecology (Washington DC) 84:2042-2050

Zelenev VV, Berkelmans R, van Bruggen AHC, Bongers T, Semenov AM (2004) Daily changes in bacterial-feeding nematode populations oscillate with similar periods as bacterial populations after a nutrient impulse in soil. Appl Soil Ecol 26:93-106 